\title{
A New Introductory Course in the Engineering Education at the University of Tromso
}

\author{
Gjengedal Arne ${ }^{1, *}$, Schive Tor ${ }^{2}$ \\ ${ }^{1}$ Department of Engineering and Safety, Faculty of Science and Technology, the Arctic University of Norway, Norway \\ ${ }^{2}$ Department of Engineering Science and Safety IVT, Faculty of Engineering Science and Technology, \\ the Arctic University of Norway, Norway
}

Copyright $(2016$ by authors, all rights reserved. Authors agree that this article remains permanently open access under the terms of the Creative Commons Attribution License 4.0 International License

\begin{abstract}
In 2011 a new national curriculum for the education of engineers was established in Norway. The objective of the curriculum is to ascertain that engineering education is professionally oriented, integrated, research-based and has a high academic standard. Institutions are instructed to facilitate a holistic approach to the engineering profession, which integrates social science, technology, science and mathematics. A new introductory course for engineers was defined, and since 2012 every education institution in Norway has given freshmen engineering students the introductory course. The course should focus on the common aspects of engineering rather than discipline-oriented topics, motivate and create identity, and include social science. The guidelines accompanying the course are vague and it has been a challenge for academic staff to establish and run the introductory course. A survey has been carried out, and this paper presents the status of the introductory course three years after implementation. Examples from various engineering programmes in Norway will be presented. At UiT the course is called "Introduction to Professional Engineering Practice and Working Methods" (10 credit points). The course changed from 2012 to 2014, and new changes are considered for 2015. It is a "toolbox" for the students with elements useful in engineering: CAD, project work, report writing, laboratory work, data analysis, engineering economics, introduction to history of technology, technology in society and engineering ethics. The course gives an overview of the engineer profession with lectures from local industry. Different experiments include model wind turbine; measurement of dust in suspension; measurement of air quality; level, pressure and flow control in fluids; and measurement of temperature with different instruments.
\end{abstract}

Keywords Introductory Course in Engineering Education, Norwegian Curriculum for Engineering Education, Toolbox for Engineering Students

\section{Introduction}

In 2011, a new national curriculum for the education of engineers [1] was established in Norway. The objective of the curriculum is to ascertain that engineering education is professionally oriented, integrated, research-based and holds a high academic standard.

The institutions are instructed to facilitate a holistic approach to the engineering profession which integrates social science, technology, science and mathematics. A new introductory course was defined, and since 2012, every engineering education institution in Norway has given freshman engineering students the introductory course.

The course should focus on the commonalities of the engineering profession rather than discipline-oriented topics, motivate and create identity, and the course should include social science. The guidelines accompanying the course are vague and it has been a challenge for the academic staff to establish and run the introductory course.

The Department of Engineering and Safety [2] has four bachelor degree programmes in engineering: Automation, Process and Gas Technology, Nautical Engineering, and Safety and Environmental Engineering.

\section{National Programme and Survey of Introductory Courses}

This chapter gives an overview of the national programmes for engineering education, and a survey of the introductory course in Norwegian engineering education.

2.1. National guidelines for engineering education

The new national guidelines for engineering education [1] was approved by the Norwegian Ministry of Education and Research in February 2011 and implemented by the education institutions at the start of the 2012 autumn semester. The guidelines gives a detailed description of the education of engineers. In chapter 2, learning outcomes (qualification) of engineering education is defined as: 
- Knowledge

- Skills

- General competence

The learning outcome is specified and explained. The programme should ensure equality in learning outcomes between the institutions and facilitate mobility. Common to all programmes is that institutions should be able to document how the national qualifications are obtained in the study programme, as well as study field and course level. The students will achieve the same learning outcomes. The institution has the freedom to choose the content, organization and assessment used to achieve the results.

In chapter 3 [1] general guidelines for the structure and contents are described using standardized national terminology. A study is made up of courses and groups of courses. A degree in engineering has four subject categories, where some courses are compulsory, and other topics are elective to define an education profile. A programme of study is a coherent course of study made up of topics and topic groups. A study may have several specializations.

A programme of study consists of programme modules, and the individual courses that will collectively fulfil the requirements for learning outcomes. Curriculum name and description must be in accordance with content. Information and communication technology are integrated and used as a tool in education, both technical and pedagogically. Institutions should have close contact with the relevant sectors of engineering during both preparation and implementation of the programmes.

A bachelor's degree in engineering is obtained after completion of the study. The candidate must have passed at least 180 credits consisting of the following subject groups:

- 30 credits common topics (mathematics, engineering professional systems thinking, and introducing methods for engineering profession and work)

- 50 credit programme topics (technical subjects, science (physics and chemistry) and social studies)

- 70 credits technical specialization courses for each engineering programme, including the bachelor thesis

- 30 credits elective courses

Chapter 4 [1] "Characteristics of new engineering education", states that quality in engineering education is described by characteristics and associated indicators. Characteristics and indicators will contribute to the continuous development of quality. An education of high international quality demonstrates these characteristics and performs well against the indicators. The characteristics give institutions the opportunity to compare programmes across institutions. The characteristics are:

- Integrated and holistic education

- In front of professional updating

- $\quad$ Updated and varied teaching and assessment
- Research and development orientation

- Profession competence and practical skills

- International competence

- Interdisciplinary, innovation and entrepreneurship

- $\quad$ Student effort and study mastery

- Engineering formation

This chapter also gives a detailed description of the characteristics. For the introductory course, characteristic VIII emphasize the engineering profession. The group of common topics will contribute to the students study mastery, motivates and raises awareness about the student's choice of study, and provides training in study skills. Computing training, writing practice, reading instruction and presentation skills are a focus of the study.

Chapter 5 [1] of the national guidelines specifies indicators for successful application of the characteristics of VIII. These are:

- The study environment, teaching and learning methods, and assessment stimulates to increased student effort and study mastery.

- The first semester motivates for the engineering profession and study programme, and stimulate the study environment for the field of engineering, and across study programmes.

Chapter 6 [1] of the national guidelines specifies learning outcomes for programmes for civil engineering, computer science, electrical, chemistry and mechanical engineering, and for selected topics like mathematics, sciences and social studies. It also gives a detailed description of the introductory course and a learning outcome description in attachment 4.

\subsection{Survey of Introductory Courses}

The survey ([3] first presented by T. Schive at a national conference) is based on a review of course descriptions and syllabuses for a variety of introductory courses at Norwegian university colleges and universities. The survey took place three years after the new curriculum was implemented. There are fifteen colleges and universities in Norway that offer engineering programmes at the bachelor level. Engineering educational programmes have very different sizes, from Bergen University College, with more than six hundred engineering students per year, to Sogn og Fjordane University College with approximately thirty engineering students per year. Table 1 provides an overview of institutions with engineering programmes, the number of introductory courses per institution and number of students who graduated in the introductory course in 2013 per institution (data from database of higher education, DBH [4]). The table also shows obtained documentation in addition to course description. 
Table 1. Introductory courses in Norwegian engineering educations [3]. From 1.1.2016 Buskerud and Vestfold UC and Telemark UC are merged to UC of Southeast Norway, Aalesund UC, Gjøvik UC and Sør-Trøndelag UC are merged and included in Norwegian University of science and Technology (NTNU) and Narvik UC is merged and is a part of UiT.

\begin{tabular}{|c|c|c|c|}
\hline $\begin{array}{l}\text { Institutions } \\
\text { (UC - University College) }\end{array}$ & $\begin{array}{l}\text { Number of } \\
\text { intro. courses }\end{array}$ & $\begin{array}{l}\text { Total number of } \\
\text { students on intr. } \\
\text { courses }\end{array}$ & Documentations from 2014 \\
\hline Buskerud and Vestfold UC & 2 & 256 & Syllabus (Vestfold) \\
\hline Aalesund UC & 2 & 150 & $\begin{array}{l}\text { Syllabus for automation, computer science and } \\
\text { civil engineering }\end{array}$ \\
\hline Bergen UC & 5 & 616 & $\begin{array}{l}\text { Syllabus for electro, chemistry, project for civil } \\
\text { engineering }\end{array}$ \\
\hline Gjøvik UC & 2 & 209 & Lectures online \\
\hline Narvik UC & 4 & 295 & Syllabus and project info \\
\hline Oslo and Akershus UC & 5 & 411 & $\begin{array}{l}\text { Syllabus for chemistry, web resources for } \\
\text { Electrical and Electronic Engineering }\end{array}$ \\
\hline Østfold UC & 2 & 178 & Syllabus (all engineering programmes) \\
\hline Sogn og Fjordane UC & 1 & 30 & - \\
\hline Sør-Trøndelag UC & 6 & 501 & $\begin{array}{l}\text { Project info for Chemistry and Materials } \\
\text { Technology. Syllabus for Chemistry, Computer } \\
\text { Engineering, Materials Technology, Electrical, } \\
\text { Mechanical and Logistics Engineering }\end{array}$ \\
\hline Telemark UC & 1 & 171 & Syllabus \\
\hline Stord/Haugesund UC & 1 & 140 & - \\
\hline $\begin{array}{l}\text { Norwegian University of Life } \\
\text { Sciences }\end{array}$ & 1 & - & - \\
\hline University of Agder & 1 & 362 & \\
\hline University of Stavanger & 5 & 441 & Lectures online \\
\hline $\begin{array}{l}\text { UiT - The Arctic University of } \\
\text { Norway }\end{array}$ & 1 & 101 & $\begin{array}{l}\text { Project for civil engineering } \\
\text { Syllabus }\end{array}$ \\
\hline
\end{tabular}

Online course descriptions are reviewed for all introductory courses, but because the course descriptions can be very general, it has been necessary to obtain curricula etc. from fall semester 2014 for some of the introductory courses. Teaching plans usually provide a detailed overview of the teaching programme on a weekly basis, with a brief description of the professional content. The documentation is supplemented with phone calls and email correspondence when there has been a need for clarifications, and such communication has mainly been with professionals who teach the introductory course.

It is common that the institutions have several variants of the introductory course, either in the form of several course codes or parallel sessions in a common course. In total, there are about forty varieties of the introductory course in Norway. In some cases, there are practical reasons for having more than one introductory courses, e.g. to split the production of credits between departments or because the institution has several campuses. All study programmes have defined one course of ten credits as the programme's introductory course, but the course name may vary. There is no study that has split up the introductory course, or merged it with other topics. The introductory course is usually in the first semester. Colleges in Bergen, Oslo and Sør-Trøndelag who have high student numbers, have separate introductory courses for each engineering education programme, for example: civil engineering, computer science, electrical, chemical and machine engineering, and these are taught independently. At several university colleges, the introductory course consists of one common part with a general theme, and one study specific part. University colleges with few engineering programmes and few students choose to give one introductory course (due to limited resources).

A survey of the first version of the course at Gjøvik UC, Østfold UC, Buskerud UC, Vestfold UC and University of Agder UiA was presented at a conference in 2012 [5]. At Gjøvik UG the students had mandatory coursework consisting of 3 individual multiple choice exercises, participation in laboratory experiments and excursions to local industry, and writing a report. Assessment was based on project and individual professional article. The survey was conducted among the students (Quest back), with some common questions and supplementary questions from each institution. Key questions (problem) in the survey were:

- Lectures and project are not well enough coordinated

- Many lecturers increasing need for information

- Many topics makes the course fragmented

- The course is too early in the study program

The author's recommendation for the future was:

- Later start of the project

- Fewer lecturers and fewer topics

- Reducing the level of ambition

- Test covering the whole syllabus

- Interdisciplinary project groups

As another example, from autumn 2015 at Aalesund UC, about half of the lectures cover common issues to all the engineering programs, and the other half is especially for each program [6]. The assessment (passed/failed) is based on semester paper, project assignment (assessment portfolio). 
UiT had a survey (quest back) autumn 2015, but the response among the students was only about $20 \%$, and the results were on average level. The teachers also had a discussion about what changes should be made, whether written examinations should be skipped, if the scope and length of the project period should be increased, if the project should be assessed (A-F) etc. We agreed not to make changes in 2016, but wait until 2017 when the course will be coordinated with IVT-faculty (former Narvik UC).

A publisher consider to write a textbook that covers most of the curriculum, and if several institutions use the new textbook (for the general part of the curriculum), the course will be more equally among the various institutions.

\section{Introductory Course at UiT}

This chapter presents course description and implementation at the UiT - The Arctic University of Norway.

\subsection{Course Description}

At UiT the course is called "Introduction to Professional Engineering Practice and Working Methods" (10 credit points). The course description [7] is almost identical to the national guidelines. The following description is from the automation programme 2014 (which is identical to the other programmes).

Contents:

- Engineering profession, the engineer's role in society

- The history of technology

- Using computers/software

- CAD (Computer Aided Design)

- HSE (health, safety and environment)

- Measurement techniques

- Data collection methods

- $\quad$ Project work, project organization, report writing

- $\quad$ Ethics

Knowledge:

- The candidate has a basic understanding of the engineering profession and the engineer's role in society and workplace.

- The candidate has knowledge to see technology in both historical and forward-looking perspective.

Skills:

- $\quad$ The candidate can identify engineering issues, seek the necessary information and assure the quality of this as a basis for problem solving.

- The candidate is familiar with basic processes of innovation and innovation in connection with project work.

- The candidate is familiar with methods of data collection.

- The candidate may use technical drawing as a communication aid.
General competence:

- The candidate is aware of environmental and ethical consequences of technological products and solutions.

- The candidate is familiar with how he/she can share their knowledge and experiences with others, both written and oral, and can cooperate in a group.

- The candidate can use modern computer tools in their engineering.

Course form: Lectures, project, laboratory and exercises.

Assessment is based on an individual examination within CAD $(40 \%)$ and a written examination $(60 \%)$. To participate in the written examination, the project - as well as any other requirements for compulsory work must be approved. To participate in the CAD examination, mandatory work in this subtopic must be approved. Both parts must be passed to achieve a grade. The grades are A-F.

\subsection{Syllabus and Implementation}

The syllabus is a detailed description of the weekly content, responsible lecturer, working requirements and an index of literature. The smaller topics (like history of technology, ethics, engineering profession, energy theory, intellectual property rights (IPR), report writing and project theory) are spread out between the larger parts (computer aided construction; electro technology; measuring technique; data collection and analysis; laboratory and project work and engineering economics). As there are students from every engineering program and several (experienced) lecturers, it is challenging to plan and accomplish the course.

The course is a "toolbox" for the students with elements useful in engineering education: CAD, project work, report writing, laboratory work, and data analysis. Other topics are placed in the introductory course because they are too small for a course of ten ECTS, and do not match other topics or courses. Those topics (like engineering economics, ethics, IPR, HSE) are relevant as a professional engineer.

The overview of the engineering profession presents a broad selection of engineering work, working conditions in Norway, and job prospects in local industry for UiT engineering programmes. One of our former students working in a local company gives a lecture of his working experiences.

History of technology gives an overview of national and local industry and the (offshore) oil industry. Also the perspective of what you need (of tools and technology) to survive in the arctic from the first inhabitants after the last ice age $10-12.000$ years ago. The importance of marine (fishery) and maritime (development of boats), local natural resources (minerals and mining, hydroelectric power, fish), cornerstone businesses, industrial clusters, space science and earth observation (from satellites), innovations and research-based new business are highlighted.

In ethics, there are lectures with formal definitions and discussion groups on ethical dilemmas. 


\subsection{Computer Aid Construction (CAD)}

Computer Aided Construction (or Design as in the acronym CAD) is in the first part of the course where students learn to use Inventor [8]. Software training in computer-aided design (CAD), where students make 3D-models of physical objects and produce engineering drawings, is included in the introductory course. The motivation for including CAD in the course is to provide a tool for the core engineering activity: the design and development of technical devices. Engineering drawings in general are considered relevant for all engineering branches, and the students are introduced to the standardized ways of communicating technical solutions through drafting and drawings. The CAD-training is mainly taking place in a PC-lab where the students are using the Autodesk Inventor computer software. Their skills are developed through practicing under supervision. The CAD-training is threefold, they produce their own parts electronically, they learn how to assemble parts into technical devices, and finally they learn how to make standardized technical drawings. One of the assignments consists of modelling a pipe clamp (Figure 1) which is handed out to the students, and they present their solution by standardized engineering drawing. The pipe clamp is chosen because it demands a variety of techniques for modelling.

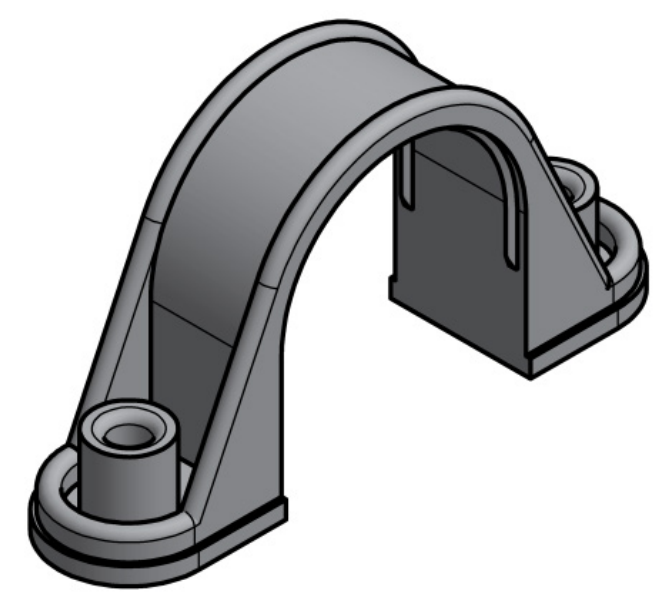

Figure 1. Pipe clamp.

In 2013, the assessment was based on a so-called reversed engineering task where students were asked to choose their own tool, component, gadget, toy etc. The students were given two weeks to model the chosen physical object. The lecturer approved the proposed object on the date the exam commenced. The examination answer consisted of engineering drawings of the model, and the physical objects were handed as guidance for the external examiner. The assessment was based on the level of difficulty and extensiveness of the modelling, and the quality of the engineering drawings. The exam contributed positively to the learning outcome, but more than a hundred unique drawings made the assessment too time-consuming. Figure 2 is an example of an exam answer.

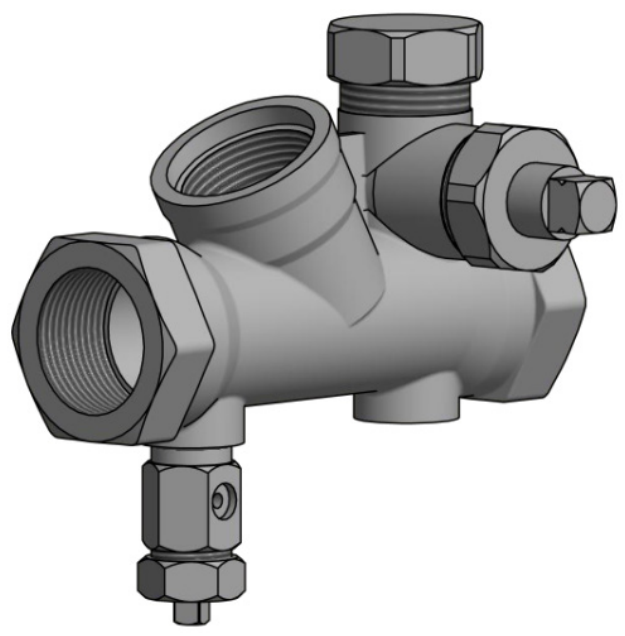

Figure 2. Example of a component.

\subsection{The Project}

The project is to perform an experiment in which students work in groups of 3-5 (preferably 4). The project content:

- Plan the project with detailed plan for the experiment, measurements, and data collection.

- The plan must be approved by the supervisor.

- Carry out the experiment and data collection

- Analyse the data and make a conclusion

- Write the report (following guidelines for report writing)

- Report and data analyses (in Excel) is delivered through Fronter (UiT's Learning Management System)

- The report will be commented by the supervisor before final submission.

- If the report is not approved, a revised report has to be delivered after a week.

- The report must be approved to get access to the final exam.

From 2011 to 2013 the students could select different experiments:

- Power production of model wind turbine.

- Measurement of dust in suspension.

- Measurement of air quality.

- Level, pressure and flow control in fluids.

- Measure of temperature with different instruments.

In 2014 all students carried out the same experiment, measuring temperatures with several instruments. The reason for this was that the department (IIS) moved in to a new building on campus, and the laboratories were not complete.

As an example, details of the wind turbine experiment are described ([9], figure 3). In the theoretical part of the report, the background of wind power, construction of the wind turbine and the power production of wind turbine is described. In the experiment, wind speed from the fan can 
be varied (and measured with anemometer), different blades with different profiles (aerodynamic characteristics), number of blades, and the pitch of the blades can be varied. The project plan must describe the experiment. The power of each experiment is measured and analyzed. The experiment should verify that wind power in an open air stream is proportional to the third power of the wind speed, proportional to the area described by the turbine, and proportional to the density of the air (Wikipedia, [10]). In addition, the best blade profile and number of blades under different conditions should be verified.

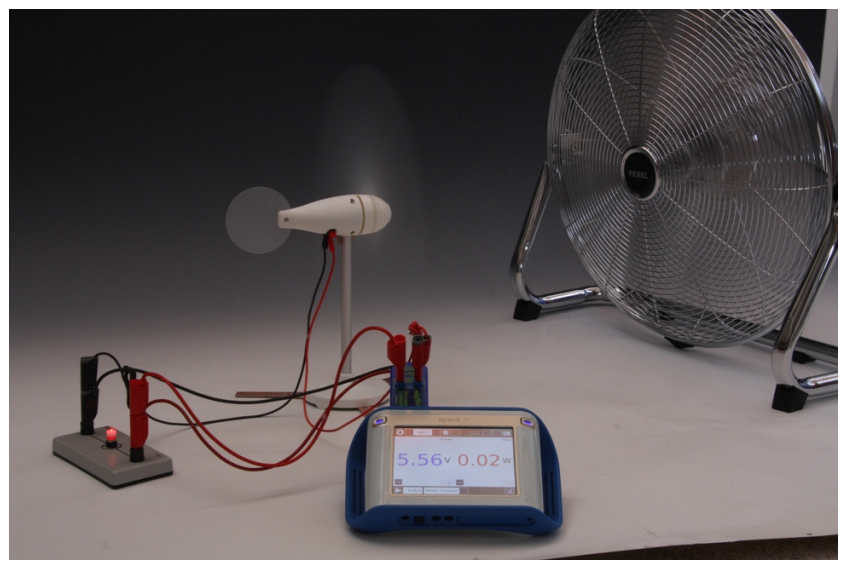

Figure 3. Wind turbine experiment [7].

In 2015 the project period (four weeks) was carried out separately for each programme with lectures in theory for the project and laboratory work. The teachers of the programmes were responsible for supervision.

As an example, the nautical students should write the report in the format of a paper for a scientific journal article. They could choose from a list of topics including "Integrated Bridge Systems", "Intentional Grounding of Ships", "Fire on Large Passenger Ships", "Ship Collisions in Clear Visibility", "Navigation of High Speed Crafts in Norwegian Confined Waters" and "Hull Types for High Speed Crafts" [11].

\section{Conclusions}

The national framework has several elements that must be included in the education of engineers. The introductory course includes several of those; it also gives the student a useful toolbox for further study.

The survey indicates that there are large variations of the course in the Norwegian engineering programmes.

At UiT, the course has been revised from 2012 to 2014. In 2015 , the projects were specific for each engineering programme, and the teachers of each programme were responsible for supervision and definition of experiments relevant for the programme, similar to the experiments from 2011 to 2013.

The structure of universities and university colleges in Norway is changing, the number of engineering programmes will be reduced, and the same programme will be offered at several campuses. As a result of the process, UiT are merging with Narvik University College, which has several engineering education programmes. The plan is to coordinate the study programmes from 2017. Therefor a discussion of changes in the introductory course is postponed to 2017.

\section{Acknowledgements}

We would like to thank the Department of engineering and safety, University of Tromsø for support to the project and travel grants. We will also thank Julie U. Gjengedal and Steve Jackson for proofreading and comments.

\section{REFERENCES}

[1] "Nasjonale retningslinjer for ingeniørutdaning", The Norwegian Association of Higher Education Institutions, http://www.uhr.no/documents/Retningslinjene_endelig_versj on til_KD 2406 til pdf.pdf. Last accessed 15 March 2016.

[2] Department of Engineering and Safety, Faculty of Science and Technology, UiT The Arctic University of Norway, $\mathrm{http} / / /$ en.uit.no/ansatte/organisasjon/hjem?p dimension_id=8 8141\&p_menu=42374. Last accessed 15 March 2016.

[3] T. Schive, "Didaktiske refleksjoner om ingeniørfaglig innføringsemne", MNT-konferansen 2015, Bergen 18.-19. Mars 2015, http://www.realfagsrekruttering.no/wp-content/u ploads/2014/10/17-Schive.pdf. Last accessed 15 March 2016.

[4] Database for Statistics on Higher Education (DBH), http://dbh.nsd.uib.no/index.action. Last accessed 15 March 2016.

[5] F. Johansen, Ingeniørfaglig innføringsemne, evaluering av gjennomføring høsten 2011 ved $\mathrm{HiG}, \mathrm{HiOf}, \mathrm{HiBu}, \mathrm{HiVe}$ og UiA. Konferanse om ingeniørutdanningen - ny rammeplan, nye muligheter. 12.-13. november 2012, Scandic Hotel Oslo Airport, Gardemoen.

[6] W. Rekdalsbakken, IF100614 Introduksjon til ingeniørfaget. Automasjon, Data og Elkraftsystemer - 2015. Høgskolen I Ålesund.

http://studiehandbok.hials.no/shb/studiehaandbok/studiehaan dboeker/2015_2016/emner/teknologi_og ingenioerfag/bache lorgradsemner_i_teknologi_og_ingenioerfag/fellesfag_tekno logi_og_ingenioerfag/if100614_introduksjon_til_ingenioerfa get. Last accessed 10 May $201 \overline{6}$.

[7] "TEK-1010 Innføring i ingeniørfaglig yrkesutøvelse og arbeidsmetoder- 10 stp" (Course description), Department of Engineering and Safety, Faculty of Science and Technology, UiT The Arctic University of Norway, http://uit.no/studietilbud/emner/emne?p_document_id=3684 02. Last accessed 15 March 2016.

[8] Inventor, 3D CAD software for mechanical design, http://www.autodesk.com/products/inventor/overview. Last accessed 15 March 2016.

[9] "Wind Pitch, Wind Power Experiment Kit, USER MANUAL", 
http://www.frederiksen.eu/da/produkter/dk_fysik_energi_11 54/vind/vnr/500545/. Last accessed 15 March 2016.

[10] "Wind Power", Wikipedia, http://en.wikipedia.org/wiki/Wind _power. Last accessed 15 March 2016.
[11] "Guidelines and Selected Topics for Student Papers in Nautical Science", Department of Engineering and Safety, Faculty of Science and Technology, UiT The Arctic University of Norway. 2015. 